Madrygal. Revista de Estudios Gallegos

ISSN: $1138-9664$

\title{
A linguaxe non sexista no CORGA: descrición e reflexión sobre as variantes empregadas
}

\author{
María Caíña Hurtado할 Eva María Domínguez Noya²; María Sol López Martínez ${ }^{3}$
}

Recibido: 14 de xaneiro de 2019 / Aceptado: 7 de outubro de 2019

Resumo. Nas últimas décadas un sector da poboación entende que o masculino se considera termo non marcado da oposición xenérica por seren tradicionalmente os homes os que posuían o poder, e non sente que as diferentes identidades xenéricas estean representadas no masculino empregado como termo non marcado. Asistimos pois á loita para acadar a igualdade entre homes e mulleres tamén dende a lingua, por unha banda facendo visible o xénero feminino, e pola outra anulando a distinción xenérica como elemento clasificador dual. Entre as opcións que se propoñen para acadar estes fins destacan a duplicación dos termos (os alumnos e as alumnas, as alumnas e os alumnos), a escolla dun termo xenérico (o alumnado) e a introdución de grafías innovadoras: os/as alumnos/as, as/os alumnas/os, @s alum$n @ s, x s$ alumnxs e, a máis recente, es alumnes. Neste traballo, tras unha breve panorámica explicativa, describiremos o uso destas formas no galego escrito actual a través dos datos recollidos no Corpus de Referencia do Galego Actual (CORGA), e proporemos abrir un debate lingüístico sobre o establecemento dun novo valor na categoría gramatical xénero e a súa posible inclusión nas gramáticas descritivas.

Palabras chave: linguaxe non sexista; corpus; galego; xénero gramatical.

\section{[es] El lenguaje no sexista en el CORGA: descripción y reflexión sobre las variantes empleadas}

Resumen. En las últimas décadas un sector de la población entiende que el masculino se considera el término no marcado de la oposición genérica por ser tradicionalmente los hombres los que detentaban el poder, y no siente que las diferentes identidades genéricas estén representadas en el masculino usado como término no marcado. Asistimos pues a la lucha para alcanzar la igualdad entre hombres y mujeres también desde la lengua, por un lado haciendo visible el género femenino y, por otro, pretendiendo anular además la distinción genérica como elemento clasificador dual. Entre las opciones que se proponen para alcanzar estos fines destacan la duplicación de los términos (os alumnos e as alumnas, as alumnas e os alumnos), la elección de un término genérico (o alumnado) y la introducción de grafías innovadoras: os/as alumnos/as, as/os alumnas/os,@salumn@s, xs alumnxsy, la más reciente, es alumnes. En este trabajo, tras una breve panorámica explicativa, describiremos el uso de estas formas en el gallego escrito actual a través de los datos recogidos en el Corpus de Referencia do Galego Actual (CORGA), y propondremos abrir un debate lingüístico sobre el establecimiento de un nuevo valor en la categoría gramatical género y su posible inclusión en las gramáticas descriptivas.

Palabras clave: lenguaje no sexista; corpus; gallego; género gramatical.

\section{[en] Non-Sexist Language in CORGA: Description of the Variants Used and Further Reflection}

1 Centro Ramón Piñeiro para a investigación en humanidades.

Correo-e: mcaihur@cirp.gal

2 Centro Ramón Piñeiro para a investigación en humanidades; Universidade de Santiago de Compostela, Departamento de Filoloxía Galega.

Correo-e: edomin@cirp.gal

3 Centro Ramón Piñeiro para a investigación en humanidades; Universidade de Santiago de Compostela, Departamento de Filoloxía Galega.

E-mail: msol.lopez@usc.es 
Abstract. Masculine markers have been traditionally used to refer to males and females collectively. However, over the past few decades a growing sector of the population has been claiming that masculine markers cannot be regarded as neutral, given that these do not include gender identities other than masculine. As this use is thought to stem from the male privileges in androcentric societies, the struggle for gender equality has also reached language. Examples show that feminine markers are being made visible while gender binarism is being disfavoured. In fact, several options are being employed, for instance, writing gendered nouns in their masculine and feminine endings (os alumnos e as alumnas, as alumnas e os alumnos), choosing a gender-neutral term (o alumnado) and developing innovative spellings (os/as alumnos/as, as/os alumnas/os,@salumn@s,xsalumn$x s$ and, more recently, es alumnes). This article focuses on the use of the aforementioned variants in present-day written Galician by analysing the data compiled in the Corpus de Referencia do Galego Actual (CORGA), with a view to launching a linguistic debate on the adoption of a new value for the gender grammatical category and its potential treatment in descriptive grammars.

Keywords: Non-Sexist Language; Corpus; Galician; Grammatical Gender.

Sumario. 1. Introdución. 2. Xénero gramatical, sexo e sexismo lingüístico. 3 . As propostas de linguaxe non sexista: alternativas e ámbitos de actuación. 4 . As variantes empregadas no CORGA. 4.1. Distribución das variantes: datos globais. 4.2. Distribución das variantes: frecuencias completas. 4.3. As grafías innovadoras e a oralidade: problemas de representación. $4.4 \mathrm{O}$ tratamento das grafías innovadoras: problemas de etiquetaxe e proposta de clasificación. 5. Conclusións. 6. Referencias bibliográficas.

Como citar: Caíña Hurtado, M.; Domínguez Noya, E. M.; López Martínez, M. S. (2019): “A linguaxe non sexista no CORGA: descrición e reflexión sobre as variantes empregadas", en Madrygal. Revista de Estudios Gallegos 22, pp. 73-91.

\section{Introdución}

A partir do último cuarto do século XX foron numerosos os debates que puxeron o foco na reflexión sobre o sexismo na linguaxe. Dende o estudo de Lakoff (1973) sobre o "lugar" da muller nas linguas ata os nosos días tivo lugar unha proliferación de traballos e discusións que tentaron discernir, dentro e fóra do ámbito estritamente lingüístico, se as linguas poden ser ou non sexistas. Neste sentido, o debate vai máis alá da mera discusión sobre este asunto: a cuestión subxacente é a de se as linguas en si mesmas poden chegar a determinar a nosa visión do mundo e o noso pensamento, así como a de se realmente os conceptos de lingua e realidade extralingüística son perfectamente disociables.

Trátase, sen dúbida, dun asunto de indiscutible actualidade. $\mathrm{O}$ feito de que un sector da poboación non se sinta representado, por exemplo, polo uso do masculino como termo non marcado da oposición xenérica ten orixinado e segue a orixinar importantes debates sobre a relación entre os conceptos de sexo (extralingüístico) e xénero (gramatical). O achegamento que se ten producido entre estes dous conceptos non só xerou opinións e reaccións de diversa índole, senón tamén propostas (p. ex., as presentadas nas guías de uso, das que falaremos máis adiante) cuxo obxectivo principal é loitar pola igualdade entre homes e mulleres dentro da propia lingua, facendo que esta deixe de invisibilizar a muller co uso do masculino como xénero non marcado. Porén, cómpre puntualizarmos que este achegamento entre os conceptos de xénero e sexo ten que ver, como apunta Moreno Cabrera (2012), con outra cuestión relevante: a propia distinción entre os conceptos de lingua natural e lingua cultivada ${ }^{4}$. Desta forma, para saber se unha lingua pode ser ou non sexista e, por conseguinte, para poder actuar contra ese sexismo, así como para lexitimar ou deslexitimar ditas actuacións, é necesario ter claro que se entende por lingua e, o máis importante, cal debe (ou pode) ser o ámbito de intervención. Só despois de clarificarmos esta cuestión cabe analizar e debater a posible evolución ou percorrido que poden ter as propostas para representar na lingua as diferentes identidades xenéricas fuxindo do masculino como termo non marcado da oposición xenérica: as duplicacións (os alumnos $e$ as alumnas ou as alumnas e os alumnos, alumnos/alumnas ou alumnas/alumnos), a escolla dun termo xenérico (o alumnado) e a introdución de grafías innovadoras: os/as alumnos/as,as/os alumnas/os,@salumn@s, xs alumnxs e, a máis recente, es alumnes.

\section{Xénero gramatical, sexo e sexismo lingüís- tico}

Unha cuestión fundamental que está detrás das propostas que tentan acabar co sexismo

4 Segundo este autor, as linguas cultivadas son "lenguas o variedades lingüísticas (que) se caracterizan por estar sometidas a una intervención explícita e intencional social, cultural e ideológicamente controlada. Estas lenguas, artificiales aunque basadas en las naturales, sí están afectadas por coordenadas culturales e ideológicas" (2012: 5). 
na linguaxe é a da relación entre a categoría gramatical xénero e o trazo extralingüístico do sexo. Tal e como indican as gramáticas, para o caso dos substantivos animados a oposición establécese por medio dunha relación semántica co sexo do referente:

A oposición de xénero fúndase no criterio semántico de 'sexo' e conta con dous morfemas, masculino e feminino, que se expresan formalmente mediante morfos de xénero e se opoñen entre si polo seu significado. A categoría ten un funcionamento moi restrinxido en galego, pois só opera en substantivos da clase léxica animada (sexuados), sobre todo nos de clase humana e en animais próximos ó home ou que teñen interese particular para el. (Álvarez e Xove 2002: 389)

Porén, isto non quere dicir que exista unha relación unívoca entre xénero e sexo. En galego, coma noutras linguas, "non hai unha correspondencia exacta entre o xénero natural da realidade extralingüística e a súa gramaticalización; non existe categoría de xénero nos vexetais, en que tamén hai exemplares machos e exemplares femias" (Ibid. 393). Ademais, tamén existen casos nos que o xénero opositivo se neutraliza malia designar un referente humano: o substantivo feminino persoa é un bo exemplo disto.

Estes factores teñen levado a definir o xénero gramatical en termos puramente formais, é dicir, prescindindo do estudo do seu significado, por consideralo unha categoría gramatical arbitraria, que non só pode gardar relación co sexo do referente, senón tamén coa súa forma ou o seu tamaño ${ }^{5}$, entre outras posibilidades (Márquez 2013: 32). Non obstante, as definicións formais da categoría gramatical non son suficientes para explicar o seu funcionamento e, en concreto, a relación que se dá entre o xénero dos substantivos e o sexo da entidade designada (cando esta pertence á clase animada de tipo humano), fenómeno cunha longa tradición e unha extensión importante en linguas coma o español:

Defendemos que en el caso de los sustantivos [+anim] y especialmente [+hum], cuando están utilizados en un ámbito específico, [+esp], la dimensión conceptual "sexo" (entre comillas siempre) motiva el género gramatical; dicho de otro modo, que el "sexo" es un "fuerte operador semántico de género gramatical (Arias Barredo, 1995). Sólo así pueden explicarse las creaciones de formas femeninas específicas constantes a lo largo de la historia de nuestra lengua y de gran productividad hoy en día. Por el miedo a confundir lengua y realidad se ha llegado a negar la vinculación indirecta entre ambas, $\mathrm{y}$ a rechazar que el género configure semánticamente una forma de contenido. (Ibid. 35)

Esta autora, pola contra, propón entender o xénero gramatical como un signo lingüístico, sen ter só en conta a súa expresión morfemática, tal como se fai desde algunhas achegas puramente formais. Así, considera que o xénero está "constituido por una relación solidaria entre una forma de expresión y una forma de contenido" (Ibid. 34). A forma de expresión non só é morfolóxica senón tamén sintáctica (a concordancia), e o contido non sempre é extralingüístico senón tamén metalingüístico. É dicir, trataríase dunha categoría mixta "de doble referencia: una lingüística (sexo, forma, cantidad, tamaño, etc.) y otra, metalingüística ('masculino'/'femenino')" (Ibid. 35). Esta clasificación si daría cabida á relación que existe entre xénero e sexo, mais tamén, como vemos, a outras relacións referenciais.

Cunha perspectiva similar, Cabeza e Rodríguez (2013: 11) sinalan que o feito de que o xénero dos substantivos non necesariamente exprese o sexo do referente "no excluye, sin embargo, que esté vivo en nuestra conciencia lingüística el recurso del género para señalar, cuando lo creemos preciso, si nos estamos refiriendo a mujeres o a hombres". Precisamente neste recurso é onde se xustifica a relación existente entre xénero e sexo e, en consecuencia, a posibilidade de interpretar o uso do masculino como non marcado, especialmente naqueles casos en que se pode crear unha ambigüidade, como un trazo de sexismo lingüístico $^{6}$. Cómpre puntualizar, con todo, que estas ambigüidades que se poden crear co emprego do masculino como non marcado teñen que

\footnotetext{
No galego temos, por exemplo, o caso de cesto/cesta.

Por razóns de espazo non trataremos aquí outros usos lingüísticos que normalmente se identifican como sexistas e que van máis alá dos aspectos puramente gramaticais (o uso de determinado léxico para referirse ás mulleres ou as connotacións negativas ou positivas de certos substantivos femininos ou masculinos, respectivamente). Estes usos aparecen descritos con moita frecuencia nas guías ou no ámbito do ensino (materiais didácticos). Sirva como exemplo a unidade didáctica realizada por Rodríguez Hevia (2003), na que se invita o alumnado de Secundaria a reflexionar, entre outras cuestións, sobre o uso de palabras como "coñazo" ou "zorro/zorra" (para referirse a un home ou unha muller).
} 
ver, segundo Márquez (2013), cunha serie de usos tradicionais que esta autora interpreta como abusivos, en tanto que presentaban o masculino como xenérico en contextos nos que realmente o referente é específico, isto é, un varón ou conxunto de varóns. A autora sinala a falta de adecuación pragmática dalgúns usos, que exemplifica do seguinte xeito:

(N)o son pragmáticamente adecuadas expresiones como la Declaración de los Derechos Universales del Hombre y del Ciudadano (Asamblea Nacional constituyente francesa: 1789) porque se estaba utilizando el masculino "genérico" para hacer una referencia específica: aunque se definían los derechos personales y colectivos como universales (...) el sujeto referencial real eran los ciudadanos franceses varones, y todos los hombres sin excepción, pero en ningún caso se contemplaba la condición de las mujeres (...). (2013: 127)

Desta forma, a autora considera que serían usos abusivos aqueles nos que, xa for porque o contexto extralingüístico (a realidade social) así o determina, xa for porque a interpretación do interlocutor non se corresponde coa intención do locutor, o masculino non actúa como xenérico porque designa unha realidade específica (o referente non é calquera sexo, senón só o masculino). A coincidencia na formalización destes dous tipos de masculino (xenérico e específico) debería salvarse, sostén Márquez, por medio dunha especificación para desambiguar a expresión (por exemplo, coa adición dalgún outro elemento do tipo "varón"). Como isto non sucede, resulta comprensible que a conclusión sexa a asociación por extensión dos masculinos xenéricos como específicos:

Puesto que, en nuestra tradición, el uso "universal" escondía en realidad una referencia específica, se puede concluir que el masculino no se ha usado como un verdadero universal, de ahí que cuando decimos expertos o ministros mantengamos una representación mental de estos grupos que solo recoge la presencia masculina (...). Por tanto, es por esta ambigüedad por lo que el masculino genérico se revela como insuficiente e impreciso, ya que no solo no designa con transparencia la realidad, sino que incluso nos impide percibir o imaginar cambios en situaciones, aunque se estén produciendo de hecho (Ibid. 129)
Tendo en conta o anterior, a noción de sexismo lingüístico baséase na concepción de que existen certos usos lingüísticos que teñen a súa orixe nunha situación discriminatoria dentro da propia comunidade lingüística. Tal e como sosteñen Cabeza e Rodríguez (2013: 8), esta noción defínese como unha "distribución inicua de prácticas lingüísticas a partir de la preeminencia de un género gramatical con base en motivaciones ideológicas de índole cultural y tradicional". Dito doutro xeito, unha situación de sexismo dentro da propia sociedade tería producido, dentro da propia lingua, a preeminencia dun xénero gramatical concreto (por exemplo, o feito de que en determinados momentos da historia as mulleres non puidesen acceder a certos postos de traballo - pensemos, como mostra, nas deputadas- provocou que non existisen formas femininas para designar esas profesións). Este é o presuposto fundamental que seguen aquelas persoas que, xa for de xeito individual xa for colectivo, defenden a necesidade de loitar contra o sexismo na linguaxe para poder atanguer tamén mudanzas na sociedade, xa que se parte da idea de que a linguaxe "crea mundos" e é capaz de determinar a nosa forma de interactuar coa sociedade (Moure 2012: 87). Esta loita contra a discriminación tradúcese normalmente en propostas de diversa índole, en xeral destinadas a ámbitos específicos da comunidade, e que se poden atopar en maior ou menor medida nos textos escritos.

\section{As propostas de linguaxe non sexista: al- ternativas e ámbitos de actuación}

Antes de comezarmos coa descrición das propostas de linguaxe non sexista máis relevantes na nosa lingua e tamén no ámbito hispánico, é preciso tratarmos unha cuestión inicial que podería estar no fondo dalgunhas das contestacións e debates que estas teñen xerado dentro e fóra do ámbito académico. Unha das críticas máis frecuentes a estas propostas é a da súa suposta pretensión de intervir de xeito artificial e premeditado na lingua espontánea ${ }^{7}$, que debe ser só propiedade de quen a fala, e sen ter en conta as recomendacións das normas e gramáticas $^{8}$. Mais, como sinala Moreno Cabrera (2012), é fundamental saber se a pretensión é realmente intervir de maneira directa na lingua

Véxanse Pérez-Reverte 2006 ou Bosque 2013.

8 No Libro de estilo de la lengua española según la norma panhispánica a RAE reafírmase no rexeitamento a estas propostas e indica, con respecto ao uso do masculino como non marcado, que dende o punto de vista lingüístico "no hay razón para pensar que este género gramatical excluye a las mujeres" (2018: 21). 
espontánea ou natural ou se, pola contra, as propostas van dirixidas a un determinado tipo de lingua cultivada, que si podería estar afectada por cuestións ideolóxicas:

Las lenguas cultivadas se crean con unos determinados fines y a partir de una serie de manipulaciones de carácter cultural e ideológico. Precisamente, las guías de uso lingüístico no sexista suelen ir destinadas al lenguaje administrativo (una de ellas lleva en el título la expresión Manual de lenguaje administrativo no sexista), judicial o político, que son variedades en las que se puede y se debe intervenir de modo consciente de acuerdo con parámetros ideológicos. (Moreno Cabrera, 2012: 6)

Ademais, este autor tamén puntualiza que hai que discernir se o que se pretende é reflexionar e actuar no uso da lingua ou na propia competencia lingüística, pois, indica, só nos usos ou actuacións lingüísticas é onde interveñen os factores ideolóxicos:

En la actuación lingüística sí intervienen de forma clara y a veces decisiva aspectos sociales e ideológicos sobre los que es posible, y muchas veces deseable, intervenir. No hay una gramática fascista, pero sí hay un discurso fascista; no hay una gramática machista pero sí hay una actuación lingüística o discurso machista o sexista. (Ibid. 2)

Ou tamén, en palabras de Cabeza e Rodríguez (2013: 8), “(1)a lengua no es un sistema ajeno a la cultura en la que se desarrolla; lejos de eso, podría entenderse como el resultado de fundir el código con la adaptación biológica y con el contexto histórico-social". Hai que clarificar, polo tanto, que estamos ante un problema que atinxe o discurso, os usos lingüísticos concretos e que, en consecuencia, as propostas de linguaxe non sexista non pretenden intervir deliberada e directamente na lingua natural e espontánea, senón en determinados tipos de lingua cultivada.

Tendo en conta o anterior, é preciso coñecermos tamén de onde veñen estas propostas, así como analizar o seu ámbito de actuación e as alternativas que nelas se recomendan. Neste senso, alén de posibles posturas individuais (Moure 2012), a difusión das propostas de linguaxe non sexista máis coñecidas vén da man das guías de linguaxe non sexista, cuxa propia existencia xa ten sido, como sabemos, bastante criticada (Bosque 2013). Non obstante, a maior parte destas guías teñen o seu fundamento nas recomendacións suxeridas polo Comité de Ministros do Consello de Europa no ano 2007. Estas recomendacións teñen como fin a defensa e preservación dos dereitos da muller e da igualdade entre homes e mulleres, conforme se expón no Convenio Europeo de Dereitos Humanos (CEDH) e na Carta Social Europea. Entre as suxestións establecidas no documento, indícase así mesmo a necesidade de empregar unha linguaxe non sexista, especialmente no sector público, nos medios de comunicación e no ámbito educativo:

La utilización de un lenguaje que refleje y trate con el mismo valor y la misma dignidad la presencia, la situación y el papel de mujeres y hombres en la sociedad es simultáneamente un aspecto esencial de la igualdad entre mujeres y hombres y un medio de conseguir una igualdad material (...). Las acciones de los Estados miembros deben tener como objetivo el fomento de la utilización de un lenguaje no sexista en todos los sectores, en particular, en el sector público, así como en todos los niveles y en todas las formas de enseñanza y los medios de comunicación. (Consello de Europa 2007: 6)

Como vemos, o ámbito de actuación é concreto: segundo este documento, son os organismos públicos os que deben loitar pola utilización dunha linguaxe non sexista. Non se fala, neste caso, da lingua espontánea ou natural, mais non debemos identificar a lingua espontánea coa oralidade e pensar que estas recomendacións só fan referencia ao plano da escrita. Así, enténdese que, por exemplo, os discursos políticos, nos que son moi frecuentes as duplicacións, non son un exemplo de lingua espontánea, en tanto que requiren un maior grao de elaboración ou, cando menos, reflexión e, ademais, podería argumentarse que en moitos casos este tipo de manifestacións orais teñen detrás un soporte escrito. Estamos, seguindo a denominación de Moreno Cabrera, ante unha intervención sobre un tipo específico de lingua(s) cultivada(s), xa for na súa vertente oral xa for na escrita, e os posibles efectos que estas intervencións teñan na lingua natural non son fáciles de adiviñar, como tampouco o son os efectos que poidan ter certas recomendacións das Academias:

¿Qué efectos pueden tener las recomendaciones de las guías de lengua no sexista en la lengua natural espontánea de todos los días? Es muy difícil, si es que es posible, responder a esta pregunta con seguridad: en el funcionamiento de las lenguas intervienen tantos factores que (...) es imposible saber si acabarán arraigando o no o, como se dice a veces equivocadamente, arruinando o degenerando la lengua. Pero esta misma pregunta se puede hacer sobre las nume- 
rosísimas proscripciones lingüísticas que aparecen en el Diccionario panhispánico de dudas (RAE y Asale 2005) (...). ¿Hará caso la gente corriente a lo que dice ese diccionario o quedará todo ello como curiosidad filológica a modo de Appendix Probi? (Moreno Cabrera 2012: 7)

Nas citadas guías acontece o mesmo que no documento do Consello de Europa, pois a maior parte están dirixidas a ámbitos específicos e case todas se promoven desde organismos oficiais: gobernos de comunidades autónomas, sindicatos, universidades e/ou outros centros educativos etc. Así, por exemplo, desde a Universidade de Santiago de Compostela (USC) propóñense uns Criterios de linguaxe non sexista (Bermúdez e Cid 2011) que teñen como obxectivo principal "evitar, na medida do posible, a linguaxe sexista" (2011: 5). Ademais, estes criterios pretenden intervir en determinados tipos de texto, adaptando as propostas para cada tipo específico: textos narrativos e descritivos comúns, principalmente aqueles que atinxen á vida universitaria, textos normativos, textos científicos, formularios, cartelaría e outros textos coma os correos electrónicos ou cartas formais. Desta forma, en ningún momento se explicita a intención de intervir directa e deliberadamente na fala espontánea. Tampouco se fai referencia á lingua espontánea na Guía para un uso da linguaxe non sexista nas relacións laborais e no ámbito sindical (Bravo e Antón 2015), en cuxo título xa se indica o contexto específico de intervención.

As propostas das diferentes guías para loitar contra a linguaxe sexista son diversas, aínda que a maior parte están dirixidas a fuxir do uso abusivo do xénero masculino como non marcado, especialmente nos textos escritos. Entre as alternativas que se propoñen destacan a duplicación dos termos, presentados como varias unidades ortográficas (os alumnos e as alumnas, as alumnas e os alumnos) ou como unha soa (alumnos/alumnas, alumnas/alumnos), o emprego dun termo xenérico ou aglutinador (o alumnado) e o uso de diferentes grafías innovadoras: ou ben as que especifican os dous xéneros (os/as alumnos/as, as/os alumnas/os), ou ben aquelas que crean artificialmente novos termos coa fin de englobar o masculino e o feminino e, indo máis alá, de romper co binomio do xénero e entendelo como unha construción da identidade que flutúa dentro dun contínuum (@salumn@s,xs alumnxs).

Estas últimas, ademais do emprego de termos aglutinadores, destácanse por presentaren unha dupla vantaxe: logran escapar do binarismo e "evitar a repetición e os seus posíbeis efectos discordantes, esa fatiga" (Moure 2012: 101). Porén, estas grafías innovadoras que rompen co binarismo (@e ' $x$ ') presentan unha pexa insalvable, e é que só son efectivas na escrita, por canto non é posible trasladar á oralidade o seu emprego dado que son impronunciables ${ }^{9}$. Mesmo dentro do propio feminismo faise fincapé na imposibilidade de verbalización, o que provoca escepticismo ante esta solución, xa que "ao se tratar dun simple soporte na escrita, esixe que na lectura tomemos unha decisión e temen que quen le tenda a seleccionar o masculino e, por exemplo, «asociación de escritor@s»se lea como «asociación de escritores»" (Moure 2012: 100).

Malia seren, xunto cos termos xenéricos (alumnado) e outras solucións coma os cambios na redacción (por exemplo "cada estudante" en lugar de "o estudante"), as alternativas preferentes nas guías ${ }^{10}$ para determinados tipos de texto (a duplicación aconséllase para os textos formais, legais e científicos, mentres que a barra relégase aos formularios), tamén a duplicación dos termos e o uso da grafía innovadora 'o/a' reciben senllas críticas, fundamentalmente polo feito de que as repeticións poden atentar contra o principio de economía da linguaxe. Mais como sosteñen Mázquez (2013) ou Álvarez Mellado (2018), por unha banda, a economía lingüística é só un dos factores que rexen o funcionamento das linguas, e pola outra, é habitual "sacrificala" en prol dunha maior expresividade. Por último, no caso de que realmente a economía lingüística fose o factor principal que rexe o funcionamento das linguas, cabería cuestionarse se poderían existir recursos coma o da sinonimia.

O emprego das grafías innovadoras non binarias (@e 'x'), no entanto, en moitas ocasións

9 Como se verá no apartado 4.3., este feito fai que o recurso máis empregado na oralidade sexa o da duplicación, a pesar de que se documente algún caso anecdótico no que a grafía coa barra se leva á oralidade. Un caso diferente é o da proposta innovadora de utilizar o -e (todes) como morfema xenérico, que xa goza dunha notable aceptación no ámbito das redes sociais, entre outras razóns porque, como indica Álvarez Mellado (2017), resulta "fácil de pronunciar, morfológicamente claro, lingüísticamente económico, socialmente inclusivo". Aínda non sabemos, con todo, se esta proposta pode chegar a transcender as redes e trunfar na fala, espontánea ou non.

$10 \quad$ Véxase Bermúdez e Cid 2011. 
fica relegado a textos informais nas recomendacións das guías, quizais pola ausencia de aceptación por parte das Academias (Moure 2012: 101), que, como no caso da Real Academia Española, consideran que o uso destas grafías atenta contra as regras gráficas e morfolóxicas da lingua (RAE 2018: 2) ${ }^{11}$, ou porque, como xa indicamos, só se poden empregar no plano da escrita.

Deseguido imos comprobar se estas recomendacións das guías se fan efectivas nos textos escritos en galego na actualidade e, para iso, a continuación analizaremos os datos que nos fornece o Corpus de Referencia do Galego Actual (CORGA).

\section{As variantes empregadas no CORGA ${ }^{12}$}

O CORGA é un corpus documental que abrangue cronoloxicamente dende o ano 1975 ata a actualidade. Os documentos, codificados na linguaxe estándar XML (eXtensible Markup Language), conforman distintos tipos de textos representativos do galego actual: xornais, semanarios, revistas, blogs, ensaios e textos de ficción (novelas, relatos curtos, obras de teatro e guións televisivos). Ademais, na versión 3.0 incorpórase tamén o rexistro oral, con transcricións de programas de radio da década dos 90 . A consulta en liña do corpus, totalmente libre e de balde, está dispoñible no enderezo http:// corpus.cirp.gal/corga.

A recuperación da información e a realización de buscas que requiren un alto grao de abstracción lingüística facilítase grazas á etiquetaxe automática de todos os documentos que conforman o corpus co emprego do Etiquetador/Lematizador do Galego Actual (XIADA) ${ }^{13}$. Este etiquetador foi desenvolvido de maneira conxunta polo Centro Ramón Piñeiro para a investigación en humanidades e o grupo COLE das universidades da Coruña e Vigo. O enriquecemento coa etiquetaxe automática permite, xa que logo, diferentes tipos de buscas: con ou sen expresións regulares, por palabra(s) completa(s) ou partes de palabra(s), por categoría gramatical, trazos morfolóxicos ou lemas. Pódense empregar, así mesmo, unha serie de parámetros de selección que teñen que ver con diferentes criterios de clasificación textual combinables entre si: período temporal, tipo de documento ou área temática, entre outros.

No CORGA podemos atopar numerosos exemplos dalgunhas das variantes de linguaxe non sexista presentadas anteriormente. Así, recuperamos aquí os seguintes exemplos, algúns dos cales xa foron presentados no traballo de Domínguez e Barcala (2018), que consideramos representativos de cada unha das alternativas propostas:

- Duplicación dos termos (varias unidades ortográficas):

(1) Carlos Blanco: os alumnos e as alumnas admitidos e admitidas ó programa de práctica orquestal $<$ pausa/ $>$ ehh $<$ pausa/ $>$ referiranse $<$ pausa/ $>$ reuniranse en fins de semana alternos $<$ pausa/ $>$ en horario de once a catorce trinta $<$ pausa/ $>$ para ensaios parciais $<$ pausa/ $>$ e de catro e media a oito $<$ pausa/ $>$ para os ensaios $<$ pausa/ $>$ ehh $<$ pausa/ $>$ colectivos [CORGA: Diario Cultural. 30/12/1996]

(2) En certa maneira, as alumnas e os alumnos participantes quixeron deixar claro que os recursos para salvar ao planeta da desfeita virán xusto da man dos axentes principalmente responsables, os seres humanos. [CORGA: Código Cero / CC2008-11/8]

- Duplicación dos termos (unha unidade ortográfica):

11 Ao contrario do que acontece con estas grafías, o uso das duplicacións e da barra non sempre se proscribe. Así, a RAE indica que, a pesar de non seren necesarios na maior parte das ocasións debido ao carácter non marcado do masculino, os desdobramentos resultan naturais cando se empregan como forma de cortesía (por exemplo, ao comezo dun discurso) ou en casos nos que "pueda quedar alguna duda de que las personas de uno y otro sexo están incluidas: Habia desheredado a sus hijos y a sus hijas" (2018: 21). Tampouco rexeitan o emprego da barra naquelas ocasións en que a súa utilización (sempre que non sexa abusiva) se considere imprescindible, isto é, cando se utilice para indicar alternativa, xa for de xénero xa for, por exemplo, de número: "director/es, padre/madre, a la atención del / de la responsable" (RAE 2018: 130-131).

12 Debido ao seu deseño, o tipo de documentos que integra e a pouca representatividade dos últimos anos, no outro corpus xeral non terminolóxico existente en galego, o Tesouro Informatizado da Lingua Galega (TILG), só documentamos unha ocorrencia con grafía innovadora: "[...] en fin, pola súa desinteresada colaboración, son os destinatarios do noso agradecemento, e en especial, todos aqueles que nos deron información ou nos prestaron material: Alumnos/as do Colexio Público Castrelo de Cambados, especialmente á promoción de 1984 e a Cristina Lorenzo" [TILG: A. Leiro Lois e X. R. Daporta, As telleiras (cabaqueiros), Ir Indo, 1993].

13 Véxase http://corpus.cirp.gal/xiada/. 
(3) Rosa Álvarez: En canto ás preguntas que están plantexadas eu, claramente, diría que isto é unha profesión, que ser actor/actriz en Galicia é unha profesión para min. [CORGA: Teatro do Noroeste / TDN1996-02/2]

(4) De tratar de achegar un pouco de xustiza á historia da informática [que, como todas as historias, non sempre foron escritas por plumas desinteresadas], é do que trata precisamente este número 64 que vostede, lectora/ lector, ten entre mans. [CORGA: Código Cero / CC2008-10/1]

- Termo xenérico:

(5) o criterio das familias en infantil permitiría que o alumnado non escoitase nin chío na lingua do país até os seis anos. [CORGA: Sermos Galiza / SG2012-09-21/5]

- Grafías innovadoras inclusivas $\sim$ xenéricas:

(6) Leve ó/á seu/súa benedictino/a favorito/a a este remanso e non se arrepentirá. [CORGA: Galicia Internacional / GI1996-07/19]

(7) O máis rechamante é o feito de que o galego non é requisito para ser xuíz/a, fiscal ou secretaria/o xudicial, que son corpos estatais. [CORGA: Galicia Hoxe / GH2011-03-07/59]

(8) Investigadoras/es, historiadoras/es e diversos colectivos cívicos amosan a súa preocupación pola deriva do museo. [CORGA: Sermos Galiza / SG2012-06-22/11]

(9) Facendo xuntanzas na escola do pobo ou na casa d@veciñ@ se na aldea non había escola naceu Preescolar na Casa. [CORGA: Sermos Galiza / SG2012-06-22/20]

As variantes con ' $\mathrm{X}$ ' maiúsculo (alumnXs) e con asterisco '*' (alumn*s) documéntanse unicamente nun texto ensaístico como información metalingüística:

(10) O uso de xenéricos do tipo de alumnado ou cidadanía, a duplicación alumnos e alumnas_ou mesmo formas ortográficas abertamente innovadoras_alumn@s, alumn*s, alumnXs pretenden evitar que o masculino sexa considerado a forma estándar. [CORGA: T. Moure, Queermos un mundo novo. Sobre cápsulas, xéneros e falsas clasificacións, Galaxia, 2012]

Porén, o CORGA 3.0 non rexistra ningunha ocorrencia do ' $\mathrm{x}$ ' minúsculo ( $x$ s alumnxs), e teremos que agardar a próximas actualizacións para documentala, con todo, só anecdoticamente polo momento:
(11) Hai programación cultural non institucional e amigxs. [CORGA: Sermos Galiza / $S G 2014-08-28 / 43]^{14}$

A práctica inexistencia no corpus desta variante talvez poida deberse a ser esta a grafía máis innovadora ou porque, pola súa alta frecuencia de uso, aínda que non na posición de morfema de xénero, senón formando parte do lexema, o galego tende a rexeitala (sería estraño encontrar esta grafía substituíndo, por exemplo, o morfema de xénero masculino ou feminino no substantivo $\operatorname{bruxo}(s) / \operatorname{bruxa}(s)>\operatorname{bruxx}(s)$ ?).

Tamén é frecuente encontrar casos nos que se emprega máis dunha variante nunha mesma secuencia. Nas ocorrencias seguintes podemos ver combinacións de barra e arroba (12), e de barra, duplicación e arroba (13):

(12) Ademais das axudas á incorporación de moz@s á actividade agraria, engadíanse outras como as de mellora das estruturas de produción das explotacións, o asesoramento ou o fomento de métodos de produción compatíbeis co ambiente, en que se primaba a condición de agricultor/a nov@. [CORGA: Sermos Galiza / SG2012-09-14/8]

(13) Que pexas viviron ou pensan que hai para un/ha autora ou autor nov@ á hora de se achegar ao sistema editorial, á hora de publicar? [CORGA: Sermos Galiza / SG2012-11-30/24]

Noutras ocasións documéntanse incongruencias causadas por non empregar os termos inclusivos en todos os casos dentro dunha mesma secuencia (exemplos 14 a 17). Ás veces isto prodúcese incluso malia apareceren combinacións de máis dunha alternativa (17):

(14) A meus cuñados/as: Picón, Marina, Olga e Marisa [CORGA: R. X. Losada, O xene da chuvia, Ediciós do Castro, 2005]

(15) O longo debate comeza por saber cal será o sexo do terceir@en cuestión. [CORGA: C. Franco, Palabras contadas / VII, Xerais, 2006]

(16) Como se os galegos/as non fósemos sensatos. [CORGA: Sermos Galiza/SG2012-11-09/4]

(17) Coñezo listas electorais tecidas co máximo coidado, intentando harmonizar afiliados con candidatos estrela como quen conxunga fío e agulla; hai quen cre tanto en si mesmo que pensa que, con encabezar el/ela mesmo/a a recua de aspirantes, xa chega. [CORGA: Galicia Hoxe / GH2007-03-02/86]

14 Non dispoñible no CORGA 3.0 en liña, senón nun texto que formará parte dunha versión posterior. 
Alén dos exemplos anteriores, tamén atopamos algunhas ocorrencias nas que, por paralelismo coa flexión xenérica tradicional do tipo español española, o emprego da@ crea formas inexistentes, o que constata unha limitación destas grafías naquelas formas cuxo masculino singular remata en consoante:

(18) A pesar dos datos, non hai unha resposta política para o sector, manténdose o continuísmo nas campañas de promoción turísticas que se centran en atraer@visitante español@. [CORGA: Sermos Galiza / SG2012-08-31/12]

(19) Xacio Baño: Imos ver, eu creo que a clave é apoiar@ creador@. [CORGA: Sermos Gali$z a / S G 2012-09-28 / 25]$

Tal e como suxiren Domínguez e Barcala (2018: 293), "estes casos deben verse só como descoidos no celo por acadar unha expresión non sexista, o que leva a que non se repare en que aquí a ‘@' non substitúe as vogais ‘ $a$ ', ‘o’ou ' $e$ ', como fai en alumn@ ou mestr@, senón que (...) engade un carácter no masculino". Do mesmo xeito, tamén se documentan contextos nos que o uso da barra '/' non resulta axeitado por dar lugar a inconsistencias que, a semellanza do que indica Gutiérrez (2018), nuns casos atentan contra o sistema (exs. 20 e 21), é dicir, contra ese "marco formal que establece las posibilidades de variación o de combinación que permite la lengua", mentres que noutros (22), en todo caso, atentan contra a norma (aquilo que se considera "correcto" nun determinado momento), moito máis susceptible ao cambio:

(20) Cada un tiña o seu lugar preferido para estar en calquera parte da inmensa mansión e todos facían vida con horarios tan diferentes que era raro, moi raro, que coincidisen dous avós/as na mesma habitación a un tempo. [Corga: M. A. Murado, Memoria de derribos, Galaxia, 1993]

(21) Outro dos xogos que os rapaces/as de tódolos ciclos da EXB non se cansan de repetir. [CORGA: X. R. Jares, Técnicas e Xogos Cooperativos para tóda-las idades, Vía Láctea, 1989]

(22) A social-democracia española, nas súas diferentes carautas foi convocada para asistir a ese casting con posíbeis actores/as ad hoc. [CORGA: Galicia Hoxe / GH2011-03-09/88]

Así pois, como podemos ver, a barra presenta limitacións provocadas por cambios nas grafías das formas femininas e masculinas. Aplicando a distinción sistema fronte a norma aos exemplos 21 e 22, o sistema non permite que despois de 'c' veña a vogal 'a' en galego -tería que ser ' $\mathrm{z}$ '-, polo que, como a partir de rapaces/as se crea visualmente *rapacas, o sistema rexéitaa. En cambio, ante a forma actoras que se crearía a partir de actores/as, é a norma, mutable como sabemos, quen indica que esa forma non é correcta, senón que o é actrices.

Ata o momento recompilamos algúns dos exemplos máis representativos das variantes de linguaxe non sexista documentadas no CORGA. Non obstante, cómpre analizarmos tamén de xeito cuantitativo a distribución que presentan estas alternativas no corpus, tendo en conta non só as frecuencias por períodos temporais, senón tamén os diferentes tipos de documentos nos que se atopan.

\subsection{Distribución das variantes: datos globais}

Antes de describir polo miúdo as variantes das grafías innovadoras e a súa distribución, cómpre unha pequena explicación sobre por que non temos en conta as formas duplas de máis dunha palabra e as dificultades para a obtención das conformadas por unha única unidade gráfica.

Se atendemos, primeiramente, á duplicación dos termos, debemos sinalar que as posibilidades de recuperación de información do corpus imposibilitan a análise de datos naqueles casos en que temos máis dunha unidade ortográfica (os alumnos e as alumnas, os alumnos e alumnas, as alumnas e os alumnos, as alumnas e alumnos etc.).

Por un lado, o CORGA non contén información semántica, co que é imposible restrinxir as procuras a substantivos animados de tipo humano. Por outra banda, a extracción das diversas estruturas que dan cabida á duplicación de substantivos devolvería unha inxente cantidade de ruído, que convertería en irrealizable a análise dos datos. Mostra disto é que, facendo uso da recuperación mediante etiquetas, a estrutura relativa á combinación de substantivo común masculino, seguido de conxunción coordinante e seguido de determinante feminino que á súa vez preceda un substantivo común feminino ${ }^{15}$

15 Na modalidade de consulta por elementos gramaticais creamos 4 liñas para a análise de catro elementos gramaticais sucesivos e cubrimos as caixiñas correspondentes ás etiquetas de cada elemento cos seguintes datos: $\mathrm{Scm}$ ? $+\mathrm{Cc}+$ *df? + Scf?. Con esa procura obtemos todos os substantivos masculinos, singulares e plurais, seguidos da conxunción $e$ ou ou seguidos dun determinante e un substantivo femininos, singulares ou plurais. 
devolve 14.923 resultados, entre os que non só aparecen os casos tipo os alumnos e as alumnas que nos interesa analizar, senón tamén multitude de combinacións tipo $o$ abandono $e$ a soedade, os allos e as fabas e mesmo casos con substantivos animados humanos que non corresponden ao fenómeno que estudamos: $\mathrm{Na}$ igrexa, o cura, propoñialles un problema aos seus poucos alumnos e moitas alumnas. Agora ben, á parte do hercúleo esforzo que suporía a análise manual de todos os resultados extraí$\operatorname{dos}^{16}$, persistiría a imposibilidade de extraer datos estatísticos contrastivos, polo que desbotamos a análise polo miúdo deste padrón.

Igual que nos casos de duplicación grafados en varias unidades, a extracción daqueles nos que a duplicación se produce nunha mesma unidade ortográfica, tipo alumnas/alumnos, non é factible tampouco por idénticos motivos: revisión manual de miles de casos (15.014 en concreto), e imposibilidade da obtención de estatísticas dende a aplicación de consulta do corpus, posto que non presentan unha estrutura formal individualizada ${ }^{17}$. Non obstante, si presentan unha peculiaridade que nos vai permitir individualizalas xunto coa súa frecuencia de uso: estas unidades son descoñecidas para o etiquetador automático, polo que malia que a través do módulo que ten incorporado aventura unha caracterización morfosintáctica, non lles vai asignar lema, o que nos permite, dende fóra da aplicación de consulta, a extracción de todas as formas que non presentan lema coa súa frecuencia de uso ${ }^{18}$. É a partir desta listaxe ${ }^{19}$ de onde obtemos a relación de formas duplas unipalabra que se rexistran nos documentos do CORGA. Así, para esta alternativa obtemos un total de 95 ocorrencias de 44 formas diferentes, das cales 28 só se documentan cunha aparición. A forma máis frecuente para esta estrutura é $a c$ tor/actriz e o plural actores/actrices, con nove aparicións para cada un dos valores numéri$\cos ^{20}$. Cómpre ter en conta, non obstante, que neste caso tamén se atopan diferenzas na distribución dos termos, é dicir, na orde xenérica. Así, comprobamos que a orde máis frecuente é a de termo masculino/termo feminino, xa que supón o $86,32 \%$ das ocorrencias, mentres que a orde termo feminino/termo masculino apenas representa o $13,68 \%$ das ocorrencias:

\begin{tabular}{|l|l|l|l|}
\hline Orde xenérica & Ocorrencias & Formas diferentes & Formas máis frecuentes \\
\hline termo masculino/termo feminino & 82 & 35 & $\begin{array}{l}\text { actor/actriz [9] }{ }^{21} \\
\text { actores/actrices [9] } \\
\text { un/unha [8] } \\
\text { el/ela [6] }\end{array}$ \\
\hline termo feminino/termo masculino & 13 & 9 & $\begin{array}{l}\text { maternidade/paternidade [3] } \\
\text { muller/home [2] } \\
\text { ás/aos }[2]\end{array}$ \\
\hline
\end{tabular}

Táboa 1. Distribución das formas duplas segundo a súa orde xenérica

16 Á estrutura anterior habería que sumar outra idéntica coa inversión do xénero dos elementos para dar cabida ás ocorrencias tipo as alumnas e os alumnos: Scf? + Cc $+* \mathrm{dm}$ ? + Scm?, o que nos devolve un total de 14.102 casos. Mais habería tamén que facer esas mesmas buscas sen que o segundo substantivo estivese precedido de determinante, ou sexa, Scm? + Cc + Scf? e Scf? + Cc $+\mathrm{Scm}$ ?, para cubrir as pautas alumnos e alumnas e mais alumnas e alumnos, que nos devolvería respectivamente 28.379 e 25.896 resultados. En suma, algo máis de 83.000 resultados.

17 A única peculiaridade é a presenza da barra, pero esta non é exclusiva destes casos, xa que non só aparece como variante do modelo alumna/o, senón opoñendo termos (proa/popa), relacionando termos (calidade/prezo), dando cabida á sinonimia (informe/memoria), na presenza de unidades de medida $(\mathrm{km} / \mathrm{s})$, con enderezos web (www. consumer.es/saude) etc. A extracción de */* (ou sexa, un ou máis caracteres seguidos de / e seguidos de un ou máis caracteres) devolve 15.014 resultados.

18 A finalidade desta listaxe é mellorar o sistema de etiquetaxe mediante a incorporación de novas entradas no lexicón, a corrección de erros en entradas xa existentes e a identificación de pequenas áreas lingüísticas en que máis problemas se producen, por exemplo os enderezos web, enderezos de correo electrónico ou abreviaturas e identificadores, co fin de facilitar o seu recoñecemento automático.

19 Extraemos todas as formas con '/' deste arquivo, formado por 5193 unidades, e revisámolo manualmente para seleccionar os casos concretos. A diferenza de resultados entre este arquivo e a procura no CORGA débese á ausencia/ presenza de espazo ao redor da barra, pois no arquivo non hai máis dunha palabra ortográfica por liña, mentres que no CORGA a busca co comodín '*' conmuta tamén a posible presenza dun espazo en branco entre o segmento que precede e segue a barra.

20 A alta frecuencia deste termo explícase pola súa presenza na revista de temática teatral Teatro do Noroeste.

21 A cifra entre corchetes desta columna indica o número de ocorrencias da forma en cuestión. 
Esta preeminencia da orde masculino/feminino podería estar relacionada cunha tendencia xeral á anteposición do masculino que en moitos casos se desaconsella nas propias guías, xa que se considera que "esta opción implica o mantemento do statu quo, e xerarquiza, ao presentar como "eterno secundario", o feminino" (Bermúdez e Cid 2011: 7). O que se recomenda, pola contra, non é darlle a volta á orde imperante en todos os casos, senón alternar, na medida do posible, entre as dúas posibilidades de orde xenérica. Porén, como vemos, os datos que nos ofrece o corpus indican que estes consellos das guías para reducir esta tendencia da orde preferente do masculino non se están a cumprir nos textos en galego.

No caso das grafías innovadoras, a consulta das ocorrencias no CORGA e tamén na listaxe de formas sen lema achega abondosos casos do uso da '@, e da '/, aínda que as alternativas diferentes que recolle esta última son máis amplas, debido á gran diversidade de desinencias que devolven as buscas, tal e como podemos ver na seguinte táboa:

\begin{tabular}{|c|c|c|c|c|c|}
\hline & $\begin{array}{l}\text { Ocorrencias } \\
\text { Listaxe de formas } \\
\text { sen lema }\end{array}$ & $\begin{array}{l}\text { Formas } \\
\text { diferentes }\end{array}$ & $\begin{array}{l}\text { Formas máis } \\
\text { frecuentes }\end{array}$ & 1 aparición & Forma máis frecuente \\
\hline @ & 68 & $75^{22}$ & 43 & 35 & @ [14] \\
\hline$@$ s & 1335 & 1343 & 328 & 216 & @s [234] \\
\hline o/a & 148 & $147^{23}$ & 74 & 68 & o/a [12] \\
\hline os/as & 277 & 277 & 100 & 71 & os/as [40] \\
\hline $\mathrm{a} / \mathrm{o}$ & 20 & $15^{24}$ & 16 & 14 & $\mathrm{a} / \mathrm{o}$; tenreira/o [2] \\
\hline as/os & 78 & 78 & 41 & 30 & as/os [11] \\
\hline án/á & 3 & 3 & 1 & - & cidadán/á [3] \\
\hline e/a & 1 & 1 & 1 & 1 & mestre/a [1] \\
\hline ón/oa & 1 & 1 & 1 & 1 & anfitrión/oa [1] \\
\hline $1 / \mathrm{a}$ & 2 & 2 & 1 & - & aquel/a [2] \\
\hline un/ha & 7 & 7 & 1 & - & un/ha [7] \\
\hline un/a & 2 & 2 & 1 & - & $\mathrm{un} / \mathrm{a}[2]$ \\
\hline $\mathrm{r} / \mathrm{a}$ & 67 & $53^{25}$ & 25 & 12 & educador/a [9] \\
\hline $\mathrm{z} / \mathrm{a}$ & 1 & 1 & 1 & 1 & xuíz/a [1] \\
\hline áns/ás & 2 & 2 & 2 & 2 & cidadáns/ás [1], irmáns/ás [1] \\
\hline es/as & 78 & $77^{26}$ & 35 & 19 & traballadores/as [9] \\
\hline as/es & 26 & 26 & 17 & 15 & educadoras/es [7] \\
\hline $\mathrm{x} \sim \mathrm{X}$ & - & - & - & - & - \\
\hline $\mathrm{xs} \sim \mathrm{Xs}$ & - & - & - & - & - \\
\hline$*$ & - & - & - & - & - \\
\hline$*_{\mathrm{s}}$ & - & - & - & - & - \\
\hline e & - & - & - & - & - \\
\hline es & - & - & - & - & - \\
\hline
\end{tabular}

Táboa 2. Datos extraídos do CORGA para as variantes das grafías innovadoras e as súas ocorrencias

22 A discrepancia no singular procede dos casos da @ como símbolo ou no interior de propios non tidos en conta na listaxe, mentres que a diferenza no plural orixínase pola súa presenza en nomes propios novamente no CORGA e ignorados na listaxe.

23 A discrepancia débese a conectado/as, que non salta na busca por *o/a no CORGA.

24 A discrepancia vén de educadora/or e varios casos de a/os que non saltan na consulta por *a/o no CORGA.

25 A discrepancia xorde nos casos de actor/actriz (9), profesor/alumno (1) e traballador/a-cyborg (1) que non saltan na consulta por $* r / a$ no CORGA.

26 A discrepancia orixínase no caso traballadores/as-cyborg que non salta na consulta por *es/as no CORGA. 
Como se observa na táboa, o uso da arroba nos plurais é notablemente superior ao seu emprego no singular, e o mesmo acontece coa barra na terminación -os/as, que é, ademais, a maioritaria para esta alternativa gráfica ${ }^{27}$.

Se comparamos as frecuencias globais das dúas opcións gráficas que se documentan no corpus ('@’ e ‘/'), así como as das formas duplas constituídas por unha soa unidade ortográfica, con respecto ao total de formas extraídas (2205), podemos comprobar que a arroba é a alternativa maioritaria. Isto contradí en certa medida as recomendacións das guías, nas que o uso da arroba estaba relegado a tipos de documentos concretos, normalmente de carácter informal, polo que cabería pensar que as outras opcións acabarían por ser as máis frecuentes nos textos. Ademais, a xa citada falta de aceptación da grafía '@' por parte das entidades normativizadoras, alén doutros posibles inconvenientes ${ }^{28}$, podería contribuír á hipótese de que o seu uso non estaría tan estendido como o da alternativa da barra ou o das formas duplas. Os datos do CORGA, non obstante, non corroboran dita hipótese, xa que a diferenza entre a frecuencia de uso da arroba e a da segunda opción gráfica máis empregada ('/) é de case 33 puntos porcentuais, tal e como podemos observar na seguinte táboa:

\begin{tabular}{|l|l|l|}
\hline Opción gráfica & Ocorrencias & Porcentaxe de uso \\
\hline @ & 1418 & $64,31 \%$ \\
\hline$/$ & 692 & $31,38 \%$ \\
\hline Formas duplas & 95 & $4,31 \%$ \\
\hline
\end{tabular}

Táboa 3. Datos globais da distribución segundo a grafía

Se temos en conta, ademais da opción gráfica, a terminación afectada, comprobamos que, no caso da barra, o máis frecuente é que esta sexa a terminación -o/a $(54,57 \%$ do total de ocorrencias da barra, incluíndo as formas duplas), xa for en singular xa for en plural. Séguea, aínda que con bastante distancia, a terminación co feminino anteposto $(-a / o)$, que supón o $11,97 \%$ das ocorrencias. A terceira forma con barra máis frecuente xa non é unha terminación en concreto, senón unha forma dupla: aquela que se corresponde coa orde masculino/feminino ( $10,55 \%$ do total). Porén, apenas se atoparon ocorrencias das terminacións -ón/oa, -z/a ou -l/a, tal vez porque o grupo flexivo -o/a é o máis frecuente en galego, ou porque nel se percibe con maior facilidade a oposición xenérica:

\begin{tabular}{|l|l|}
\hline $\begin{array}{l}\text { Terminacións (inclúe } \\
\text { sg e pl se o houber) }\end{array}$ & Ocorrencias \\
\hline @ & 1418 \\
\hline o/a & 424 \\
\hline e/a & 78 \\
\hline án/á & 5 \\
\hline r/a & 53 \\
\hline ón/oa & 1 \\
\hline 1/a & 2 \\
\hline z/a & 1 \\
\hline a/o & 93 \\
\hline a/e & 26 \\
\hline Formas duplas: fem./masc. & 13 \\
\hline Formas duplas: masc./fem. & 82 \\
\hline
\end{tabular}

Táboa 4. Datos globais da distribución segundo a grafía e a terminación

Como vemos, parece que unha cuestión relevante no caso daquelas alternativas que presentan barra, ben plenas - elas/eles-, ben reducidas no seu segundo compoñente-cidadán/á-, é a orde xenérica. Estas son as únicas formas nas que se visualiza a diferenciación dos dous xéneros constitutivos e nas que, en consecuencia, se pode producir a inversión na orde. Nos datos que nos ofrece a seguinte táboa podemos comprobar que a orde máis frecuente é a de masculino/feminino, o que nos indica que os textos non seguen a alternancia de orde xenérica máis ou menos equitativa que se propón nas guías:

27 Segundo os datos do lexicón de XIADA, as palabras que seguen o modelo flexivo formal tipificado por neno son 11.460 , mentres que o segundo grupo máis produtivo, o representado por aquel, contén 1678 entradas. Non é de estrañar polo tanto o predominio desta terminación.

28 Sirva como exemplo adicional o que indican Bravo e Antón (2015: 65): "se ben é un recurso posible e efectivo cando se quere non marcar o xénero (...) terase en conta como posible limitación que se trata dun recurso gráfico que non é recoñecido neste uso non sexista polos dispositivos lectores que empregan as persoas con discapacidade visual". 


\begin{tabular}{|l|l|l|} 
Orde & Ocorrencias & Porcentaxe de uso \\
\hline masc./fem. & 646 & $83,03 \%$ \\
\hline fem./masc. & 132 & $16,97 \%$ \\
\hline
\end{tabular}

Táboa 5. Distribución en función da orde xenérica

En resumo, se temos en conta os datos globais analizados ata agora, podemos establecer que a grafía innovadora que presenta unha maior frecuencia de uso no CORGA é a arroba. A alternativa menos frecuente, pola contra, é a duplicación das formas presentada como unha única unidade ortográfica. Se se engaden tamén os datos relativos ás terminacións e á orde xenérica, comprobamos que a terminación máis frecuente é $o / a$, e a orde imperante é masculino/feminino. Sirvan os seguintes gráficos como síntese dos datos das frecuencias globais:
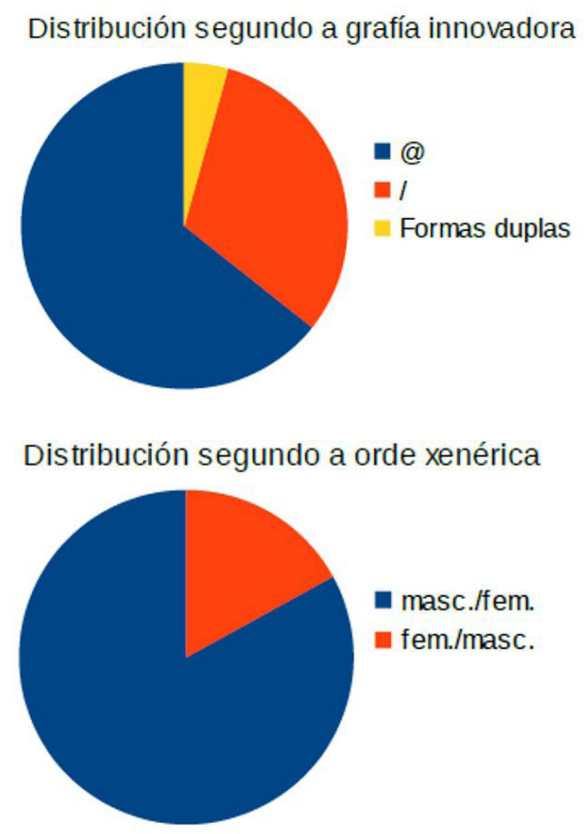

\subsection{Distribución das variantes: frecuencias completas}

Alén de termos en conta toda a diversidade de opcións gráficas para a linguaxe non sexista que nos ofrece o corpus, é interesante tamén analizarmos as frecuencias completas que presentan ditas opcións, tendo en conta non só a súa distribución global, senón tamén os datos referidos á súa distribución cronolóxica e aos distintos tipos de documentos nos que as atopamos. Cómpre indicarmos, non obstante, que a análise de frecuencias completas só pode realizarse para aquelas alternativas cuxos datos se consultaron directamente no CORGA, e non para aquelas cuxas frecuencias obtivemos da listaxe de formas sen lema. Neste apartado, por tanto, só se tratarán as variantes das terminacións con '/ e '@', e non as formas duplas constituídas por unha soa unidade ortográfica.

Tendo en conta, en primeiro lugar, a distribución por lustros, podemos comprobar que as formas con barra xa se documentan moito antes que as formas con arroba nos textos que contén o CORGA. As primeiras ocorrencias da barra datan do ano $1989^{29}$, mentres que non encontramos casos de emprego da arroba ata o lustro 2000-2004, concretamente ata o ano 2001. A maior frecuencia no emprego da '/' documéntase, non obstante, no lustro 20052009 e a partir dese momento parece que a tendencia ao seu aumento acaba por estancarse,

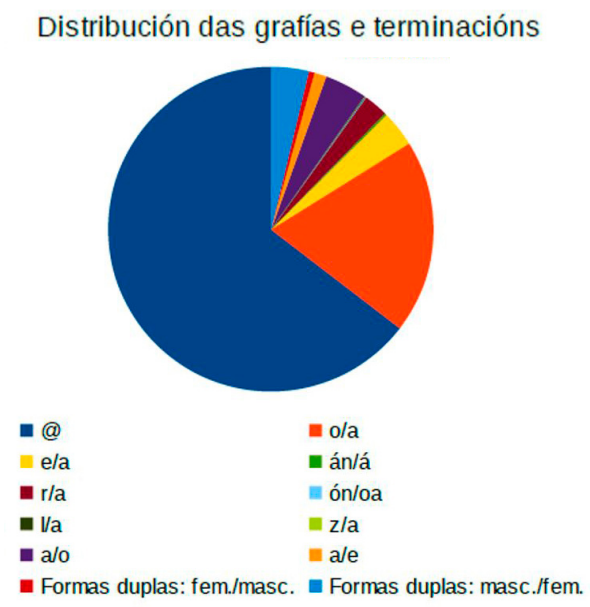

quizais pola alta porcentaxe de uso que presentan as formas coa ' @' no período seguinte (2010-2014), onde se concentra o $94,29 \%$ de ocorrencias desta alternativa cuxa utilización era ata entón residual. Debido a que se están introducindo aínda os textos que o van constituír, os datos do período comprendido entre 2015 e 2019 non permiten polo de agora tirar conclusións. Na seguinte táboa podemos ver con detalle a distribución por lustros destas dúas opcións gráficas:

29 Concretamente localízanse na obra divulgativa de X. R. Jares, Técnicas e Xogos Cooperativos para tóda-las idades, Vía Láctea, 1989. Con todo, parece que o uso destas grafías neste momento é moi limitado e só as empregan persoas que están sensibilizadas coa cuestión. 


\begin{tabular}{|c|l|c|l|l|}
\multirow{2}{*}{ Lustros } & \multicolumn{3}{|c|}{ '/ } & \multicolumn{3}{c|}{ ‘ } \\
\cline { 2 - 5 } & Ocorrencias & $\%$ & Ocorrencias & $\%$ \\
\hline $1985-1989$ & 64 & $9,24 \%$ & - & - \\
\hline $1990-1994$ & 34 & $4,91 \%$ & - & - \\
\hline $1995-1999$ & 51 & $7,36 \%$ & - & - \\
\hline $2000-2004$ & 30 & $4,33 \%$ & 10 & $0,71 \%$ \\
\hline $2005-2009$ & 280 & $40,40 \%$ & 70 & $4,94 \%$ \\
\hline $2010-2014$ & 234 & $33,77 \%$ & 1337 & $94,29 \%$ \\
\hline $2015-2019$ & - & - & 1 & $0,07 \%$ \\
\hline
\end{tabular}

Táboa 6. Distribución por lustros da frecuencia de uso da'/'e da '@,'

En canto ao xénero dos documentos en que se distribúen estas dúas alternativas, podemos ver que o seu uso se concentra maioritariamente nos medios de comunicación: o $71,86 \%$ das ocorrencias da barra e o $94,54 \%$ das da arroba documéntanse no xénero xornalístico. Dentro deste xénero, non obstante, parece que hai unha clara preferencia pola arroba nos xornais $(92,67 \%$ do total de ocorrencias nesta forma), mentres que a barra aparece en revistas con maior frecuencia $(43,15 \%)$ ca en xornais $(28,57 \%)$. Aínda así, a pesar de que o xénero xornalístico parece ser o máis proclive ao uso destas grafías, no caso da barra tamén encontramos un número considerable de ocorrencias no xénero ensaístico e, en menor medida, no narrativo $^{30}$. De feito, a frecuencia de aparición da barra en xornais é moi similar á dos libros $(28,14 \%)$, mentres que o emprego da arroba neste medio é minoritario $(5,50 \%)$.

Se analizamos estes datos polo miúdo, podemos ver que, dentro do xénero narrativo, atopamos un total de 38 ocorrencias da '/" en relatos curtos e 13 en novelas, mentres que para o xénero dramático só documentamos 3 . Pola contra, apenas hai aparicións da arroba neste tipo de documentos: a maior parte concéntranse, ao contrario do que acontecía coa barra, nas obras de teatro (7 ocorrencias), e só se documentaron dúas ocorrencias da '@)' en novelas e unha en relato curto. No xénero ensaístico,

\begin{tabular}{|l|l|c|l|c|}
\multirow{2}{*}{ Xéneros } & \multicolumn{3}{|c|}{ '/ } & \multicolumn{2}{c|}{ '@' } \\
\cline { 2 - 5 } & Ocorrencias & \multicolumn{1}{c|}{$\%$} & Ocorrencias & \multicolumn{1}{c|}{} \\
\hline Narrativo & 51 & $7,36 \%$ & 3 & $0,22 \%$ \\
\hline Dramático & 3 & $0,43 \%$ & 7 & $0,50 \%$ \\
\hline Ensaístico & 141 & $20,35 \%$ & 68 & $2,74 \%$ \\
\hline Xornalístico & 498 & $71,86 \%$ & 1340 & $96,54 \%$ \\
\hline
\end{tabular}

Táboa 7. Distribución por xénero da frecuencia de uso da'/'e da '@'

todos os casos de '@' (68) aparecen en obras de carácter divulgativo, quizais polo seu marcado carácter informal, segundo indican as guías, mentres que a barra, malia ser maioritaria tamén na divulgación (136 ocorrencias) si que presenta algunha aparición en artigos científicos (5 ocorrencias). No caso das publicacións en Internet, apenas se documentan casos de ambas as dúas grafías, aínda que a arroba é maioritaria: 5 ocorrencias fronte a unha única da barra.

Porén, o que parece claro é que os medios de comunicación son o contexto que máis propicia a aparición deste tipo de grafías, quizais en consonancia co que se propuña no documento asinado polo Consello de Europa: as recomendacións de uso de linguaxe non sexista ían destinadas fundamentalmente á documentación administrativa emitida por organismos públicos (á que non se lle dá cabida no corpus) e ao seu emprego no ámbito educativo e nos medios de comunicación.

Por outra parte, pareceunos tamén interesante comprobar, naqueles documentos aos que no corpus se lle asignan áreas temáticas (os que se corresponden co medio ensaístico e xornalístico), cales destas áreas se ven máis afectadas polo uso das grafías innovadoras. Como se pode constatar na seguinte táboa, para as áreas de economía e política, cultura e artes, ciencias sociais e outros (nesta área entran os deportes, a actualidade, os asuntos domésticos etc.) a opción que se prefire é a da arroba. Porén, na área de ciencias e tecnoloxía prevalece o emprego da barra fronte á outra alternativa:

30 Probablemente porque a lingua dos libros é máis coidada (lembremos que a @ quedaba relegada nas guías a usos máis coloquiais) e porque as editoriais en xeral dispoñen no seu cadro de persoal de lingüistas que actúan como revisores e correctores, os cales evitan o emprego de formas non recomendadas polas autoridades académicas. 


\begin{tabular}{|l|l|c|l|c|}
\multirow{2}{*}{$\begin{array}{c}\text { Área } \\
\text { temática }\end{array}$} & \multicolumn{2}{|c|}{ '/ } & \multicolumn{3}{c|}{ '@' } \\
\cline { 2 - 5 } & Ocorrencias & $\%$ & Ocorrencias & $\%$ \\
\hline $\begin{array}{l}\text { Economía } \\
\text { e política }\end{array}$ & 308 & $24,6 \%$ & 1040 & $44,11 \%$ \\
\hline $\begin{array}{l}\text { Cultura e } \\
\text { artes }\end{array}$ & 112 & $9,00 \%$ & 193 & $8,18 \%$ \\
\hline $\begin{array}{l}\text { Ciencias } \\
\text { sociais }\end{array}$ & 416 & $33,44 \%$ & 499 & $21,16 \%$ \\
\hline $\begin{array}{l}\text { Ciencias e } \\
\text { tecnoloxía }\end{array}$ & 216 & $17,36 \%$ & 76 & $3,22 \%$ \\
\hline \begin{tabular}{l} 
Outros \\
\cline { 2 - 5 }
\end{tabular} & 192 & $15,43 \%$ & 550 & $23,32 \%$ \\
\hline
\end{tabular}

Táboa 8. Distribución por área temática da frecuencia de uso da '/' e da '@,

Parece, así pois, que a área das ciencias e da tecnoloxía é máis proclive ao uso da barra, quizais polo seu carácter máis formal. Non resulta estraño, pola contra, comprobar que aqueles temas que adoitan ser tratados con maior frecuencia nos xornais (economía e política) presentan unha maior frecuencia de uso da arroba que, lembremos, amosaba unha frecuencia de uso moi alta neste tipo de documentos.

O que se pode concluír desta análise é que precisamente a opción gráfica máis innovadora das dúas, a que parecía non gozar de moita fortuna (Moure 2012: 100) polo seu rexeitamento tanto por parte das Academias como dalgúns colectivos feministas, é en realidade a que se emprega con maior frecuencia en case todos os contextos nos escritos en galego. As excepcións son contadas, como xa puidemos comprobar: só aqueles xéneros, textos e temas (os xéneros narrativo e ensaístico, os libros e as temáticas de ciencia e tecnoloxía) que poderían ser máis reticentes á innovación e nos que normalmente se dispón de máis tempo para a reflexión e revisión lingüística (non é o mesmo escribir un libro que unha noticia nun xornal) son os que parecen seguir os consellos das guías e as proscricións das normas, e empregan a barra por considerala, quizais, unha opción máis axeitada para o rexistro formal.

\subsection{As grafías innovadoras e a oralidade: problemas de representación}

Como xa indicamos, o maior problema que provoca o uso das grafías innovadoras é a falta dunha correspondencia na oralidade. O emprego nos textos deste tipo de formas que non son verbalizables parece obrigar a quen le a substituílas por outras alternativas de designación do xénero (Moure 2012: 100), quer optando por un dos dous xéneros, quer tratándoas como unha duplicación. Estas opcións, porén, non parecen idóneas, porque poden perpetuar a preeminencia dun xénero sobre o outro, e/ou contribuír a manter unha visión binaria sobre as identidades xenéricas. Non obstante, a realidade que amosan os textos orais que contén o CORGA é que, cando se pretende empregar unha linguaxe non sexista, acódese á duplicación. Así, para a década dos 90 atopamos, coa busca no corpus da estrutura básica da duplicación, un total de 20 ocorrencias, das que a continuación recollemos algúns exemplos:

$-\mathrm{Scm} ?^{32}+\mathrm{Cc}+\mathrm{Scf}$ ?

(23) Teresa Navaza: quen decide <pausa/> que señores e señoras $<$ pausa/ $>$ fan os programas da TVG? [CORGA: Camiño de Volta. 03/02/1994]

(24) Locutor 1: dona Elena de Borbón rematou cunha mención especial $<$ pausa/ $>$ para os homes i mulleres <pausa/> da súa xeración $<$ pausa/> para que non caian na intolerancia $\mathrm{i}$ no oportunismo [CORGA: Informativo 14:00. 25/07/1997]

(25) Carlos Blanco Vila: un pouquiño máis $<$ palabra_cortada $>$ tar $<$ palabra_cortada $><$ pausa/> tes irmáns ou irmás? [CORGA: Xamón Xamón. 04/01/1997]

$-\mathrm{Scf} ?+\mathrm{Cc}+\mathrm{Scm}$ ?

(26) Carlos Blanco: falemos $<$ pausa $/>$ de teatro en Santiago <pausa/ $>$ proseguen as representaciós para nenas e nenos $<$ pausa/ $>$ no centro comercial <pausa/> Área Central [CORGA: Diario Cultural. 30/12/1996]

(27) Vita da Cuña: son as dúas < pausa/ $>$ boas tardes $<$ pausa/ $>$ señoras e señores $<$ pausa/ $>$ noticias < pausa/> na Radio Galega [CORGA: Informativo 14:00. 17/07/1997]

31 Téñase en conta que un mesmo caso pode contabilizarse en máis dunha área temática, dado que os documentos clasifícanse tematicamente con ata tres áreas.

32 O interrogante substitúe un carácter na consulta, co que se cobren tanto os substantivos singulares coma os plurais. 
$-\mathrm{Scf} ?+\mathrm{Cc}+* \mathrm{dm} ?^{33}+\mathrm{Scm} ?$

(28) Carlos Blanco Vila: dez <pausa/ $>$ e $<$ pau$\mathrm{sa} />$ trinta e un minutos <pausa/ $>$ da mañá $<$ pausa/ $>$ imos atender as amigas e os amigos que agardan [CORGA: Xamón Xamón. 04/01/1997]

(29) Carlos Blanco Vila: seguimos $<$ pausa/ $>$ dez e trinta e tres minutos da mañá $<$ pausa/ $>$ bueno <pausa/> bueno <pausa/> de acordo $<$ pausa/ $>$ se hai publicidade $<$ pausa/ $>$ hai publicidade $<$ pausa/ $>$ logo falamos coas amigas e os amigos < pausa/> que están chamando [CORGA: Xamón Xamón. 11/01/1997]

$-\mathrm{Scm} ?+\mathrm{Cc}+* \mathrm{df} ?+\mathrm{Scf} ?$

(30) Uxío Labarta: i os homes e as mulleres $<$ pausa/> son patrimonio religioso <pausa/> no? [CORGA: Camiño de Volta. 26/09/1995]

(31) Carlos Blanco Vila: non sei si este amigo ou esta amiga tamén xogará no parque [CORGA: Xamón Xamón. 04/01/1997]

As duplicacións son, xa que logo, unha alternativa de linguaxe non sexista que se dá con frecuencia na oralidade. $O$ feito de que as grafías innovadoras como '@, ou 'x' sexan impronunciables reduce o abano de posibilidades na fala e leva a optar por solucións que, se ben poden contribuír a loitar coa perspectiva androcéntrica, perpetúan o binarismo. Unha alternativa diferente sería a do uso, cando é posible, dalgún termo xenérico do tipo alumnado, dos que tamén se documenta algunha ocorrencia nos textos orais do CORGA:

(32) Carlos Casares: cando saliron en Vigo $<$ pausa/ $>$ pois duascentas ou trescentas mil personas á rúa pola $<$ pausa/ $>$ ehh $<$ pausa $/>$ pola crisis industrial $<$ pausa $/>$ do sector naval $<$ pausa/ $>$ pois $<$ pausa/ $>$ eu recordo que o alcalde da cidade $<$ pausa/ $>$ obedecendo órdenes de $<$ pausa/ $>$ de $<$ pausa/ $>$ de $<$ pausa/ $>$ de Guerra $<$ pausa/ $>$ quedouse no seu despacho $<$ pausa/ $>$ en vez de presidir a manifestación <pausa/> ó frente da cidadanía $<$ pausa/ $>$ porque eran problemas $<$ pausa/ $>$ que el tiña $<$ pausa $>>$ como representante do pobo $<$ pausa/ $>$ na cidade de Vigo [CORGA: Camiño de Volta. 20/01/1993]

Un intento de adaptación á fala da grafía coa ‘/ rexistrámolo nun caso de texto dialogado nun documento de ficción:
(33) Faláronme na Coruña dunha praza de redactor, barra "a", para o suplemento de cultura. [CORGA: X. Borrazás, Costa Norte/ZFK, Galaxia, 2008]

Con todo, non atopamos outros exemplos similares nos documentos orais, mais debe terse presente que o rexistro oral no CORGA non é representativo do emprego do galego actual, dado que só inclúe, polo momento, transcricións da década dos 90. Será interesante ver, cando se incorpore o material relativo aos dous últimos lustros, que datos nos ofrece.

Nos corpus do galego non hai máis casos deste tipo, pero si podemos encontrar algún outro exemplo para o español (34). Trátase, así a todo, dunha opción de adaptación á oralidade moi pouco frecuente mesmo nesta lingua.

(34) RETENIDA $1 .{ }^{\text {a }}$ - - No, señor barra a. Le he contestado a su pregunta: nada, señor barra a. [CORPES: Budia, Mariam: Al soslayo. Alicante: Biblioteca virtual Miguel de Cervantes, 2005]

Estes poderían verse como intentos case anecdóticos de trasladar á fala o uso dunha grafía innovadora na escrita, o que dá conta non só das diversas estratexias que pode empregar quen fala, senón tamén da variedade de solucións que se poden adoptar fronte a un problema común á maior parte das alternativas (exceptuando, por suposto, as duplicacións e os termos xenéricos): a falta dunha correlación entre os avances que se levan a cabo na escrita para acadar unha expresión do xénero o máis inclusiva e económica posible e as alternativas reais das que podemos botar man no discurso.

\subsection{O tratamento das grafías innovadoras: problemas de etiquetaxe e proposta de clasi- ficación}

Como puidemos comprobar na análise da distribución das variantes, algunhas das grafías innovadoras que se propoñen para evitar a linguaxe sexista gozan xa dunha frecuencia de uso considerable nos textos galegos actuais. Este feito supón unha problemática tanto desde o punto de vista computacional como desde o punto de vista lingüístico. $\mathrm{O}$ feito de que as obras de referencia na nosa lingua non inclúan reflexións sobre este tipo de alternativas obriga

33 Mediante esta etiqueta extráense as diversas ocorrencias nas que o substantivo, coa modificación do valor correspondente ao xénero, está precedido dun determinante. 
a tomar, en primeira instancia, decisións de traballo para a súa etiquetaxe automática. Como sosteñen Domínguez e Barcala (2018), estas grafías xeran problemas de diversa índole no proceso de etiquetaxe automática do CORGA:

Dende o punto de vista do procesamento automático, as palabras con '@', ‘/,'‘*' ou 'X', (alumn@s, alumnos/as, alumnas/os, alumnXs, alumn*s) presentan dificultades para o seu recoñecemento. Por unha banda, son unidades para as que non consta información no lexicón; por outra banda, no corpus de adestramento só se rexistrou un caso con dobre flexión (alumnos/ as), que foi tratado provisionalmente como se estivésemos ante termos duplicados (alumnos / alumnas), co que o etiquetador non pode extraer de aí tampouco información referente á forma, o lema ou a etiqueta; por último, en relación co módulo de adiviñación, as terminacións das palabras con grafías innovadoras inciden, a efectos formais, no número e no xénero, mais non son identificables cunha clase de palabra fronte ao sufixo -mente, por exemplo, creador de adverbios-. (Domínguez e Barcala 2018: 294)

Tal e como se indica nese mesmo traballo, a decisión que se tomou para facilitar o recoñecemento automático e, en definitiva, a recuperación de información, foi implementar no lexicón de XIADA as terminacións coas grafías innovadoras naqueles grupos de derivación que se ven afectados polo seu uso. Non obstante, para a súa implementación foi precisa unha caracterización destas formas en canto ao xénero. Para isto, descartouse a súa clasificación como 'neutras', porque este xénero xa existe en galego (está presente no paradigma do demostrativo) e, alén de concordar sempre en singular, a propia etimoloxía da palabra neutro xa nos indica que a súa natureza non é a de designar varias entidades, senón ningunha ("nin unha cousa, nin a outra"). No caso das grafías innovadoras, pola contra, non é que non se queira designar ningún xénero en concreto, senón que o que se pretende é, nuns casos, facer referencia aos dous xéneros (a concepción binaria que comporta, por exemplo, o caso de alumnos/as) e, noutros, englobar todas as identidades xenéricas posibles (a concepción non binaria que temos, por exemplo, en alumnxs). Así mesmo, tampouco se poden equiparar estas formas cos substantivos comúns en canto ao xénero e tratalas como ambiguas:

Parece claro que alumn@s alumnos/as alumnas/os $\sim$ alumnXs $\sim$ alumn*s diverxen do tipo alpinista, común en canto ao xénero a nivel de palabra, pero coa posibilidade de outorgarlle o xénero feminino ou o masculino en función dos determinantes ou as concordancias que con ela se empreguen. En consecuencia, a opción de tratalas como formas ambiguas masculinas/ femininas non parece axeitada, pois [...] non hai ambigüidade nelas, sempre van posuír o mesmo valor. (Ibid. 296)

Tendo en conta estes aspectos, decidiuse escoller o termo xenérico para designar este novo valor gramatical que entendemos posúen as formas innovadoras dentro da categoría do xénero. Estas formas constitúen, en consecuencia, elementos do mesmo paradigma das formas tradicionais de expresión do xénero, incluídas todas baixo un mesmo lema ${ }^{34}$. $\mathrm{O}$ termo que escollemos para clasificalas xa aparece nas gramáticas para referirse a aqueles casos en que un xénero engloba os dous xéneros ou, aplicado ao que aquí tratamos, todas as identidades xenéricas. Por exemplo, Álvarez e Xove (2002: 394) apuntan que "(n)as zonas de Galicia en que se di normalmente raposa, é tamén o fem. o termo xenérico, e raposo o específico". Así, se puntualmente se caracteriza o masculino ou o feminino como xenéricos naqueles contextos en que se afirma que engloban os dous xéneros, parece lóxico que nestas formas, cuxa motivación principal é a de designar todas as identidades xenéricas posibles, a caracterización como xenéricas sexa inherente.

Agora ben, entendemos tamén que é competencia de toda a comunidade lingüística determinar se realmente se debe ampliar o paradigma gramatical do xénero mediante a inclusión deste novo valor. Dito doutro xeito, consideramos que podería ser relevante abrir un debate para discernir se esta decisión de traballo pode ou debe transcender os límites do tratamento computacional dos textos e afectar tamén á propia descrición gramatical das linguas.

34 Deste xeito, se se desexan recuperar por exemplo todas as formas baixo o lema alumno, non só obteremos as concorrencias de alumno, alumna, alumnos e alumnas, senón tamén alumno/a, alumnos/as, alumn@s, alumnos/alumnas etc. 


\section{Conclusións}

Os datos extraídos do CORGA permitíronnos levar a cabo unha descrición e análise das diferentes variantes de linguaxe non sexista que temos no galego actual, as cales constatan o uso dunha serie de alternativas que tentan fuxir do androcentrismo que, segundo as propostas de linguaxe non sexista, implica o uso do masculino como termo non marcado da oposición xenérica.

Vimos, así mesmo, como a súa presenza nos textos do CORGA e a necesidade de procesalas automaticamente obrigaron a realizar unha reflexión lingüística acerca do seu encaixe na gramática do galego, extensible a outras linguas románicas, e a tomar unha decisión de traballo: son formas flexionadas que pertencen ao mesmo paradigma que as formas masculinas ou femininas tradicionais, cuxo representante canónico é o mesmo lema, e que caracterizamos por presentar un novo valor para a categoría gramatical xénero que denominamos xenérico. Malia non ser a alternativa primada polas guías de linguaxe non sexista e malia ser rexeitada polas autoridades académicas, tomando como base os datos do CORGA, en galego emprégase maioritariamente a '@, (lembremos que presenta unha porcentaxe de uso de máis dun $64 \%$ ), e en menor medida a '/'.

Como falantes dunha lingua, pódese estar de acordo ou rexeitar o emprego de formas gráficas que visibilicen a muller e mesmo persigan a non clasificación tendo en conta o sexo da persoa, mais non se pode fuxir dunha realidade patente: estas formas modifican o sistema actuando sobre a categoría gramatical xénero ao incrementar os seus valores constitutivos. Establecer cantos e cales debe ser o obxecto da reflexión lingüística desa outra vía que polo de agora non aflorou, quizais porque o debate se centrou fundamentalmente en xustificar ou proscribir o cambio.

\section{Referencias bibliográficas}

Álvarez Blanco, Rosario e Xosé Xove (2002): Gramática da lingua galega. Vigo: Galaxia.

Álvarez Mellado, Elena (2017): “Todas, tod@s, todxs, todes: historia de la disidencia gramatical”, eldiario. es (https://www.eldiario.es/zonacritica/Todas-todes-historia-disidencia-gramatical_6_659044117.html).

_ (2018): “Más allá de la economía del lenguaje”, eldiario.es (https://www.eldiario.es/zonacritica/ alla-economia-lenguaje _ 6 793430676.html).

Bermúdez Blanco, Manuel e Alba Cid Fernández (2011): Criterios de linguaxe non sexista, Santiago de Compostela: Servizo de Normalización Lingüística; Universidade de Santiago de Compostela (http://www. usc.es/export9/sites/webinstitucional/gl/servizos/oix/descargas/linguaxe_non_sexista_publicado_WEB_ USC.pdf).

Bosque, Ignacio (2013): "Sexismo lingüístico y visibilidad de la mujer", Boletín de información lingüistica de la Real Academia Española 1 (http://revistas.rae.es/bilrae/article/view/120/232).

Bravo, Carmen e Eva Antón (2015): Guía para un uso da linguaxe non sexista nas relacións laborais e no ámbito sindical. [s.1.]: Secretaría Confederal da Muller de CCOO (http://www.ccoo.gal/comunes/recursos/11/pub155164_Guia_para_un_uso_da_linguaxe_non_sexista_nas_relacions_laborais_e_no_ambito_sindical.pdf).

Cabeza, Carme e Susana Rodríguez (2013): “Aspectos ideológicos, gramaticales y léxicos del sexismo lingüístico”, Estudios filológicos 52, pp. 7-27.

Centro Ramón Piñeiro para a Investigación en Humanidades (2017): Corpus de Referencia do Galego Actual (CORGA) [3.0], http://corpus.cirp.gal/corga/ [consulta: xullo de 2018].

Consello de Europa (2007): "Recomendación CM/Rec(2007)17 del Comité de Ministros a los Estados miembros sobre las normas y los mecanismos de igualdad entre mujeres y hombres" (http://www.inmujer.gob.es/publicacioneselectronicas/documentacion/Docu mentos/DE0019.pdf).

Domínguez Noya, Eva María e Francisco Mario Barcala Rodríguez (2018): "Grafías innovadoras na linguaxe non sexista: unha proposta para a súa etiquetaxe automática", en Díaz et al. (eds.), Actas do XIII Congreso Internacional de Lingüística Xeral (Vigo, 13-15 de xuño de 2018). Vigo: Universidade, pp. 291-298.

Gutiérrez, Salvador (2018): "Sobre 'pilota', 'portavoza', 'miembra' y otros femininos", El Mundo (http:// www.elmundo.es/espana/2018/02/10/5a7df963ca474179478b4698.html).

Lakoff, Robin (1973): “Language and Woman's Place”, Language in Society 1, pp. 45-80.

Márquez Guerrero, María (2013): Género gramatical y discurso sexista. Madrid: Síntesis.

Moreno Cabrera, Juan Carlos (2012): “Acerca de la discriminación de la mujer y de los lingüistas en la sociedad. Reflexiones críticas”, Infoling (http://infoling.org/repositorio/MORENOSEXISMO.pdf). 
Moure, Teresa (2012): Queer-mos un mundo novo: Sobre cápsulas, xéneros e falsas clasificacións. Vigo: Galaxia.

Pérez-Reverte, Arturo (2006): “Aceituneros y aceituneras”, El Semanal (http://www.perezreverte.com/ articulo/patentes-corso/125/aceituneros-y-aceituneras/).

Real Academia Española: Corpus del Español del Siglo XXI (CORPES), http://web.frl.es/CORPES/view/ inicioExterno.view [consulta: 20/07/2018].

Real Academia Española (2018): Libro de estilo de la lengua española según la norma panhispánica. Barcelona: Planeta.

Rodríguez Hevia, Gloria (2003): ¿Qué es...? El lenguaje sexista. Construyendo contigo la igualdad. Asturias: Consejería de la Presidencia, Instituto Asturiano de la Mujer (http://institutoasturianodelamujer. $\mathrm{com} /$ iam/biblioteca-digital/materiales-didacticos-para-la-coeducacion-construyendo-contigo-la-igualdad-n $\% \mathrm{C} 2 \% \mathrm{BA}-2 /)$.

TILG = Santamarina, Antón (dir.); Ernesto González Seoane e María Álvarez de la Granja: Tesouro informatizado da lingua galega (Versión 4.1). Santiago de Compostela: Instituto da Lingua Galega, http:// ilg.usc.es/TILG/ [consulta: 29/8/2018]. 